\title{
Model Pengembangan Pendidikan Karakter Melalui Implementasi Kurikulum 2013 Pada Lembaga Pendidikan Yang Dikelola Oleh Yayasan Islam Kota Salatiga
}

\author{
Ngamilah \\ Widya Iswara Balai Diklat Keagamaan Semarang, Indonesia \\ ngamilahbdk@gmail.com
}

\begin{abstract}
Absract
The purpose of this study was to find a model for the development of character education with the main elements of planning the development of character education programs, the implementation of character education development programs, and the effectiveness of character education development programs in three Vocational High Schools in the City of Salatiga. This research is a descriptive qualitative study using a multi-case study with a focus on the case of the development of character education that occurred in Al-Falah Vocational Schools, Diponegora Vocational Schools and the third Muhammadiyah Vocational School under the auspices of the Islamic Foundation located in Salatiga City. The findings of this study indicate the peculiarity of the model of the development of character education in vocational schools managed by Islamic foundations in the city of Salatiga, namely the habituation model, civilization, exemplary, local content and extra curricular. The peculiarities of the character development model in three Vocational Schools are in spirituality-religiosity, where this is very useful and effective in the formation of students' character.
\end{abstract}

Key Words: Model, Development, Character Education.

\begin{abstract}
Abstrak
Tujuanpenelitian iniadalah untukmenemukan modelpengembanganpendidikan karakter dengan unsur pokok perencanaan penyusunan program pengembangan pendidikan karakter, pelaksanaan program pengembangan pendidikan karakter, dan efektifitas program pengembangan pendidikan karakter di tiga Sekolah Menengah Kejuruan di Kota Salatiga. Penelitian ini merupakan penelitian kualitatif deskriptif dengan menggunakan studi multi kasus dengan fokus pada kasus model pengembangan pendidikan karakter yang terjadi di SMK Al-Falah, SMK Diponegoro dan SMK Muhammadiyah yang ketiganya di bawab naungan Yayasan Islam yang berlokasi di Kota Salatiga. Temuan penelitian ini menunjukkan adanya kekhasan model pengembangan pendidikan karakter pada SMK yang dikelola oleb Yayasan Islam di kota Salatiga, yaitu model pembiasaan, pembudayaan, keteladanan, muatan lokal dan ekstra kurikuler. Kekhasan model pengembangan pendidikan karakter di tiga SMK ada pada spiritualitas-religiositas, di mana hal ini sangat bermanfaat dan efektif dalam pembentukan karakter siswa.
\end{abstract}

Kata Kunci : Model, Pengembangan, Pendidikan Karakter.

Permalink/DOI: http://dx.doi.org/10.18326/infsl3v12i2.481-505 


\section{Pendahuluan}

Penurunan karakter bangsa pelan tapi pasti telah membawa bangsa ini menuju kehancuran. Di berbagai tempat masih muncul perilaku anarchist mulai dari kalangan pelajar, mahasiswa dan masyarakat umum. Perilaku korup di kalangan pajabat, penegak hukum, anggota legislatif masih terus terjadi sampai saat ini. Fenomena lain, kini pelajar lebih suka mendatangi Play station, diskotik, dan tempat-tempat hiburan lainnya dari pada perpustakaan, diskusidiskusi dan mengaktifkan studi-studi club (Ngamilah, 2017: 3). Dalam keadaan yang demikian, bangsa dan negeri yang besar ini harus segera berbenah diri, melakukan tindakan prefentif yang bisa dimulai dengan pembenahan karakter pada peserta didik di sekolah dengan berbagai tingkatannya.

Sebagai negara yang mayoritas penduduknya Muslim, maka dekadensi moral menjadi ancama bangsa. Oleh sebab itulah Pendidikan Karakter menjadi perhatian Negara dalam penyusunan regulasi-regulasi sistem pendididikan di Indonesia. Hal ini dapat dilihat misalnya dalam Undang-undang Sistem Pendidikan Nasional Nomor 20 tahun 2003 pasal 3, di sana disebutkan bahwa Pendidikan Nasional berfungsi untuk meningkatkan kemampuan dan menciptakan kepribadian bangsa yang bertujuan untuk meningkatnya potensi siswa agar menjadi warga negara yang beriman dan bertaqwa kepada Allah SWT, memiliki akhlakul karimah, sehat jasmani dan rohani, terampil, kreatif dan mandiri serta menjadi warga negara yang demokratis, amanah, jujur dan bertanggung jawab (Kemendiknas, 2011:7). Oleh karenanya setiap lembaga Satuan Pendidikan memiliki tugas dan bertanggung jawab akan terwujudnya bangsa yang berkualitas dan berkarakter. Sekolah dan masyarakat sebagai bagian dari lingkungan sangat memungkinkan untuk mengambil peran penting dalam mewujudkan bangsa yang berkualitas dan berkarakter tersebut. Oleh karena itu setiap sekolah dan masyarakat harus memiliki kedisiplinan dan budaya yang didalamnya memuat pesan-pesan karakter yang akan diwujudkannya. (QS al-Ahzab [33]: 21)

Penerapan Undang-undang Sistem Pendidikan Nasional Nomor 20 tahun 2003 telah membuka peluang bagi Pendidikan 
Agama Islam untuk memasuki sejarah baru, yang ditengarai dengan penguatan Sistem Pendidikan Agama Islam merupakan bagian dari pranata pendidikan Nasional. Lembaga-lembaga Satuan Pendidikan yang bercirikhas Islam seperti Madrasah dan Sekolah-sekolah yang dikelola oleh yayasan-yayasan Islam di era sekarang ini memiliki memiliki peran penting dalam pembangunan nasional di bidang pendidikan (Abdurrahman, 1996: 37).

Kota Salatiga merupakan salah satu kota di Jawa Tengah yang telah mencanangkan Kota Pendidikan. Oleh karenanya kota ini sedang memacu diri di bidang pendidikan. Seiring dengan itu muncul berbagai Yayasan Islam yang mengelola pendidikan formal yang di dalamnya tidak lepas dari penanaman nilai-nilai Islam dalam pengejawentahannya, temasuk upaya pembentukan karakter siswa. Diantara lembaga pendidikan yang dikelola oleh Yayasan Islam di Salatiga adalah SMK Diponegoro yang dikelola oleh Yayasan Imaratul Masajid wal Madaris, SMK "Al-Falah " yang dikelola oleh Yayasan Pondok Pesantren Al-Falah, dan SMK Muhammadiyah yang di kelola oleh Pimpinan Daerah Muhammadiyah Kota Salatiga.

Berangkat dari latar belakang tersebut maka penulis meneliti tiga Sekolah Menengah Kejuruan (SMK) yang berada di bawah naungan Yayasan Islam di kota Salatiga yang mengedepankan akblaqul karimah dengan fokus masalah (1) Bagaimanakah program pengembangan karakter siswa di SMK Diponegoro, SMK Al-Falah, dan SMK Muhammadiyah Kota Salatiga, (2) Bagaimanakah efektifitas program pendidikan karakter di SMK Diponegoro, SMK AlFalah, dan SMK Muhammadiyah Kota Salatiga dalam pembentukan karakter siswa, dan (3) Bagaimana kendala yang dihadapi oleh SMK Diponegoro, SMK Al-Falah, dan SMK Muhammadiyah Kota Salatiga dalam pengembangan pendidikan karakter.

\section{Kajian Pustaka}

Penelitian ini dasari oleh beberapa penelitian yang sudah dilakukan sebelumnya yang sempat terlacak oleh penulis, di antaranya adalah:

Pertama, penelitian yang dilakukan oleh Fasaufa Aflakha (2008) yang berjudul “ Peran Guru PAI dalam Pembentukan 
Kepribadian Islami Siswa melalui Budaya Agama di SMP Negeri 2 Tumpang". Metode yang digunakan dalam penelitian ini adalah kualitatif yang disajikan dalam bab pertama dan kedua. Dalam penelitian ini dinyatakan bahwa dalam membentuk kepribadian seorang Muslim, peran guru maupun Pendidikan Agama Islam benar-benar dibutuhkan khususnya dari guru bidang keagamaan, dan pelaksanaan Pendidikan Agama Islam di sekolah tersebut sudah cukup baik karena terbukti sudah mengikuti prosedurprosedur yang dipergunakan dalam melangsungkan proses belajar mengajar (Aflakha: 2008).

Kedua, penelitian yang dilakukan Ratnaning Eka Astuti (2012) Fakultas Ilmu Tarbiyah dan Keguruan UIN Malang yang berjudul "Pembentukan Karakter Siswa Berbasis Agama (Studi Kasus Di MAN Kediri II Kota Kediri)". Pendekatan yang gunakan adalah pendekatan kualitatif dengan metode deskriptif melalui rancangan studi kasus. Dalam peneltian ini dinyatakan bahwa pembentukan karakter siswa berbasis agama ini dapat diimplementasikan melalui kegiatan keagamaan, ekstrakulikuler keagamaan, serta diterapkan juga melalui kegiatan belajar mengajar yaitu dengan adanya RPP dan silabus berkarakter pada semua mata pelajaran, baik sosial, sains dan agama, juga diterapkan melalui pengembangan diri siswa serta budaya sekolah. Hasil penelitiannya menunjukan bahwa karakteristik siswa Madrasah Aliyah Negeri Kediri II memiliki karakter spiritual, solidaritas, kedisiplinan, kemandirian, tanggung jawab, respect, dan citizhensip yang bagus, yang tercermin diberbagai kegiatan dalam lingkup sekolah, dan dalam pelaksanaannya di sekolah (Astuti: 2013).

Ketiga, Penelitian yang dilakukan Mohammad Mufid (2013) yang berjudul "Strategi Pembentukan Karakter Religius Siswa di Ma'had Al-Qalam MAN 3 Malang”. Peneliti mengungkapkan hasil penelitiannya bahwa dalam pembentukan karakter religius pada siswa diperlukan strategi-strategi tertentu seperti pembelajaran yang bersifat ta'lim ma'badydan pembelajaran toleransi antar organisasi keagamaan, serta pengembangan budaya sekolah dan pusat kegiatan sekolah seperti pembiasaan dan keteladanan yang diajarkan pada siswa. Penelitian ini termasuk penelitian deskriptif kualitatif, dengan metode pengumpulan datannya menggunakan 
observasi, dokumentasi dan wawancara. Sedangkan teknik analisis datanya menggunakan analisis deskriptif kualitatif (Mufid: 2013).

Dari ketiga kajian tersebut berbeda dengan kajian yang akan penulis lakukan dari aspek latar belakang, fokus kajian dan lokasi penelitian.

\section{Kerangka Konseptual dan Alur Pikir}

Karakter biasa diartikan dengan tabiat, sifat-sifat kejiwaan, akhlak atau budi pekerti. Karakter, sifat-sifat kejiwaan, akhlak dan budi pekerti inilah yang membedakan antara seseorang dengan yang lain. Dalam pandangan Lickona yang dikutip Komarudi menegaskan bahwa karakter mencakup ilmu pengetahuan tentang kebaikan yang menimbulkan niat baik atau komitmen dan kemudian diwujudkannya sehingga akhirnya benar-benar berbuat baik (Komarudin , 2012 : 224 ). Orang memiliki karakter adalah orang yang memiliki kepribadian, budi pekerti, atau akhlak. Dengan demikian karakter identik dengan kepribadian atau akhlak. Kepribadian merupakan karakteristik atau sifat khas yang dimiliki seseorang yang berasal dari bentukan-bentukan moral Tuhan. Selanjutnya ia menambahkan bahwa karakter juga memiliki tiga hal yang saling berkaitan yaitu lingkungan, keluarga dan bawaan (Doni Koesoema A, 2007: 80 ).

Dari tinjauan diatas, Zuchdi menandaskan bahwa terbentuknya karakter ada empat hal yang saling terkait yaitu keteladan, nilai, fasilitas dan pengembangan skill. Selain itu, untuk keterwujudan program pembinaan karakter perlu adanya evaluasi nilai. Evaluasi harus dilakukan secara akurat dengan pengamatan yang relatif lama dan secara terus-menerus. (Zuchdi, 2008: 46-50)

Dalam rangka membangun karakter, Kementerian Pendidikan Nasional telah mencanangkan 18 nilai tentang pendidikan karakter bangsa untuk ditanamkan kepada para siswa melalui pendidikan formal. Ke delapan belas nilai tersebut adalah religious, dapat dipercaya, toleran, kerja keras, kreatif, berjiwa nasionalisme, menghargai prestasi, bersahabat, gemar membaca, sosial, tanggung jawab, mandiri, demokratif, rasa ingin tahu, mandiri, cinta damai, dan sportif. Selanjutnya berangkat dari delapan belas nilai tersebut 
dikembangkan dalam Grand Design pengembangan karakter di semua jalur, jenjang dan jenis pendidikan yang dapat dijadikan rujukan konseptual dan operasional dalam pelaksanaan pengembangan pendidikan karakter (Depdiknas, 2004). Membangun karakter dapat diintegrasikan dalam semua subyek dan proses belajar mengajar. Pembentukan karakter terintegrasi dalam proses pengajaran dan pembelajaran dapat dilakukan di awal, inti, dan kegiatan penutupan. Integrasi pembentukan karakter dalam kegiatan inti pengajaran dan proses pembelajaran dapat dilakukan dalam kegiatan eksplorasi, elaborasi, dan konfirmasi (Marini, 2017: 177).

Dari tinjauan teoritik tersebut, maka penelitian ini dapat digambarkan dalam skema berikut:

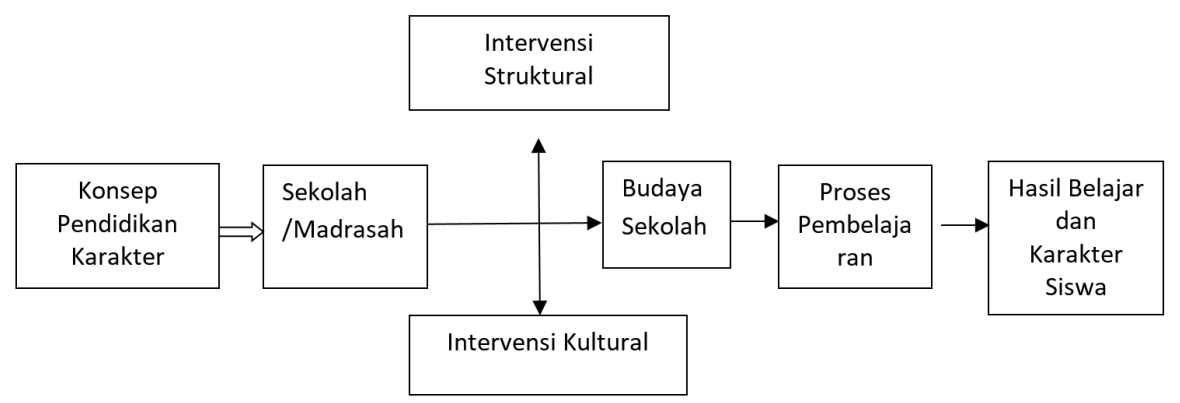

Gambar 1. Skema Penelitian

\section{Metode Penelitian}

Penelitian ini berjudul "Model Pengembangan Pendidikan Karakter dalam Implementasi Kurikulum 2013 pada Lembaga Pendidikan di Bawah Naungan Yayasan Islam Kota Salatiga (Studi terhadap SMK Diponegoro Kota Salatiga, SMK Al-Falakh Kota Salatiga, SMK Muhammadiyah Kota Salatiga) Berdasarkan judul tersebut, maka penelitian ini bersifat menggambarkan model pengembangan pendidikan karakter di SMK Diponegoro Kota Salatiga , SMK AlFalakh Kota Salatiga dan SMK Muhammadiyah Kota Salatiga. Maka penelitian ini menggunakan metode deskriptif. Sukmadinata (2005: 18) menegaskan bahwa: Penelitian kualitatif deskriptif bukan dimaksudkan untuk melakukan manipulasi terhadap perlakuan- perlakuan tertentu terhadap variabel atau merekayasa sesuatu agar terjadi pada variabel, 
tetapi semua aktifitas, situasi dan kondisi, peristiwa, aspek, komponen atau variabel berjalan sebagaimana apa adanya.

Penulis memilih pendekatan kualitatif, Bog dan Taylor sebagaimana dikutip oleh Moleong (2001: 3), mendefinisikan "pendekatan kualitatif sebagai prosedur penelitian yang menghasilkan data deskriptif berupa kata-kata tertulis atau lisan dari orang-orang dan perilaku yang dapat diamati”. Tidak jauh berbeda dengan Moleong, Sukmadinata menjelaskan bahwa "penelitian deskriptif kualitatif merupakan penggambaran keadaan secara naratif kualitatif" (Sukmadinata, 2005: 18).

Sugiono menegaskan bahwa penelitian kualitatif berfungsi menetapkan fokus penelitian, menentukan informan sebagai sumber data, pengumpulan data beserta penilaian kualitasnya, analisis data, memaknai data dan menyimpulkan atas semuanya isu (Sugiono, 2008: 18). Lokasi penelitian ini adalah tempat berlangsungnya penelitian yakni SMK Diponegoro Kota Salatiga, SMK Al-Falakh Kota Salatiga, SMK Muhammadiyah Kota Salatiga. Sumber data berupa data primer dan data sekunder. Sumber data primer diambil dari lokasi penelitian. Sumber data sekunder yang menjadi rujukan peneliti dalam hal ini adalah semua dokumen SMK Diponegoro Kota Salatiga, SMK Al-Falakh Kota Salatiga, SMK Muhammadiyah Kota Salatiga, baik berupa dokumen tertulis seperti peraturan sekolah, jadwal pelajaran, indikator kurikulum, unit plan, class letter, plan weekly, kalender akademik, akta sekolah, data jumlah siswa dan guru serta staf sekolah, struktur sekolah, data berkenaan dengan sarana dan prasarana yang dimiliki sekolah, dokumen yang berbentuk foto atau video dan data lain-lainnya. Pengumpulan data dilakukan dengan observasi, wawancara, dan kajian dokumentasi yang dipilih dalam penelitian ini yaitu: narasumber (informan), peristiwa atau aktivitas, dan tempat.

Sedangkan analisis data dalam penelitian kualitatif bersifat iterative (berkelanjutan) dan dikembangkan sepanjang penelitian. Analisis data dilaksanakan mulai dari penetapan masalah, pengumpulan data, dan setelah data terkumpulkan. Analisis yang telah dilakukan secara umum dimulai sejak pengumpulan data, reduksi data, penyajian data, dan penarikan kesimpulan atau verifikasi. 


\section{Hasil Penelitian}

Tujuan pendidikan karakter sebagaimana termuat dalam UndangUndang No.20/2003 tentang Sistem Pendidikan Nasional, adalah mencetak manusia yang berbudi pekerti luhur dan bertaqwa kepada Tuhan Yang Maha Esa (Sisdiknas, 2003). Sementara Kurikulum 2013 memiliki tujuan untuk mempersiapkan manusia Indonesia agar memiliki kemandirian hidup sebagai pribadi dan warga Negara yang beriman dan bertaqwa, mampu berkomunikasi dengan masyarakat, berperadaban, produktif, kreatif, inovatif, dan afektif, berbangsa, dan bernegara. Tujuan tersebut, menunjukkan arah, dan proses penyelenggaraan pendidikan yang berkualitas dan berbasis karakter. Kemampuan hidup dipahami sebagai kualitas sikap spiritual dan sosial dan kecakapan pengembangan pengetahuan serta penerapannya. Selaras dengan tujuan tersebut, Kurikulum 2013 memiliki karakteristik (1) Menjaga keseimbangan antara sikap spiritual dan sosial, rasa ingin tahu, kreativitas, kerja sama dengan kemampuan intelektual dan psikomotorik, (2) Satuan Pendidikan merupakan bagian dari masyarakat (3)Memiliki pengalaman belajar yang terencana dimana siswa mampu mengaplikasikan apa yang dipelajarinya di sekolah dalam kehidupan bermasyarakat serta memiliki kemampuan untuk memanfaatkan masyarakat sebagai sumber belajar, (4) Mengembangkan sikap, pengetahuan, dan keterampilan serta menerapkannya dalam berbagai situasi di sekolah dan masyarakat, (5) Memberi waktu yang cukup untuk mengembangkan berbagai sikap, ilmu pengetahuan, dan keterampilan, (6) Keahlian dinyatakan dalam bentuk kompetensi inti kelas yang terjabarkan lebih lanjut dalam kompetensi dasar mata pelajaran, (7) Kompetensi inti merupakan bagian dari pengorganisasian (organizing elements) kompetensi dasar, dimana seluruh kompetensi dasar dan proses pembelajaran diarahkan untuk mewujudkan kompetensi inti, (8) Kompetensi dasar yang dikembangkan didasarkan pada prinsip akumulatif, saling memperkuat (enforced) dan memperkaya (enriched) antar mata pelajaran dan jenjang pendidikan (secra vertikal dan horizontal).

Uraian karakteristik kurikulum 2013 di atas, dapat dipahami bahwa kurikulum 2013 berorientasi pada pengembangan pendidikan karakter peserta didik. Di mana hal ini dapat dilihat dari adanya 
integrasi baik secara vertikal dan horinsontal antar mata pelajaran dan jenjang pendidikan, demikian pula integrasi antara ranah kognitif, afektif, dan psikomotorik ( Kaimudin, 2013)

\section{Model Pengembangan Pendidikan Karakter}

Searah dengan tujuan tersebut SMK al-Falakh mencanangkan cita-citanya untuk menyiapkan anak didik menjadi tamatan yang berkompeten dan berakhlak mulia. Untuk mewujudkan Visi tersebut SMK al-Falakh memiliki lima misi yaitu (1) Menyiapkan tamatan yang menguasi IPTEK, (2) Menyiapkan tamatan yang mandiri, cerdas dan Jujur, (3) Menyiapkan tamatan yang berjiwa kewirausahaan, (4) Menyiapkan tamatan yang berkompeten di bidangnya, dan (5) Menyelenggarakan sekolah yang berkarakter. Menyimak Visi dan Misi tersebut dapat dipahami bahawa SMK al-Falakh mengedepankan karakter dalam pengejawentahan peserta didiknya. Untuk mewujudkan Visi dan Misi tersebut, telah melakukan berbagai langkah kongkrit yang dinilai sangat mendukung. Langkah-langkah tersebut diwujudkan dalam bentuk (1) Pembiasaan Spiritualitas (2) Ekstra Kurikuler (3) Keteladanan dan (4) Muatan Lokal

\section{Pembiasaan Spiritualitas}

Teori Pavlov menyatakan bahwa untuk membangkitkan respon diperlukan stimulus yang dilakukan secara berulangkali agar menjadi kebiasaan. Sehingga dengan stimulus tersebut akan memunculkan respon yang dibiasakan, (Muttaqin, 2014). Dalam Law of readiness (hukum kesiapan) dinyatakan bahwa pembelajaran baru akan membawa hasil jika peserta didik mempunyai kesiapan. Oleh karenanya, menurut Islam peserta didik yang akan belajar dianjurkan mempunyai niat yang benar dan berdo'a terlebih dahulu sebagai bentuk kesiapan peserta didik, supaya dalam kegiatan selanjutnya dapat dilakukan secara optimal (Izzatur Rusuli, 2014; 1-17). Sejalan dengan teori ini pihak sekolah melakukan pembiasaan-pembiasaan yang bersifat spiritualitas dalam bentuk (1) Berdoa sebelum memulai pelajaran. (2) Tadarus al-Qur'an selama 10 menit sebelum mulai pelajaran pada jam pertama setiap harinya 
(3) Pembacaan al-Asmaul Husna yang dilakukan setelah Tadarus al-Qur'an, (4) Pembiasaan melakukan Shalat Dhuhur berjamaah. (Joko, Wawancara 20 April 2018).

Berdoa sebelum memulai belajar yang telah menjadi kebiasaam para siswa tersebut menunjukkan telah adanya kesiapan mereka dalam menerima pelajaran yang di dalamnya termuat "niat" yang dalam ajaran Islam merupakan hal yang wajib dilakukan sebelum melakukan suatu pekerjaan niat itu sendiri sangat menentukan sikap si pelaku pekerjaan dan hasil pekerjaan yang dilakukan. Dalam kontek belajar siswa, niat tersebut akan ikut menentukan perilaku dan hasil belajar siswa. Membaca ayat-ayat al-Qur'an dengan fasih diprtlukan adanya konsentrasi secara total. Pemahaman kaidahkaidah membaca al-Qur'an yang disebut ilmu tajwid, akan mampu mencerdaskan otak siswa. Dengan membiasakan diri membaca alQur'an, otak akan menjadi terbiasa bekerja multi dimensi. Tatkala siswa membaca al-Qur'an yang secara otomatis berkonsentrasi terhadap informasi-informasi yang terdapat dalam setiap huruf, kata dan kalimat makna dan hukum tajwid yang terkandung. Demikian juga dengan alunan irama yang dilantunkan. Kedekatan dengan Al-Qur'an juga mampu meningkatkan daya kerja akal dan pikiran yang mendapat pencerahan dari cahaya al-Qur'an. (Suhail, 2014: 22 ).

Abul Aliyah sebagaimana dikutip Fajar Kurniyanto mengatakan bahwa di dalam sholat itu ada tiga unsur penting, yaitu Ikhlas, khosyah (takut) dan dzikrullah (ingat kepada Allah). Maka jika tiap sholat tidak ada ketiganya, tidaklah disebut sholat. Karena dengan kandungan ikhlas akan mengajak kepada yang ma'r uf, khosy-yah akan mencegah kepada yang mungkar dan dzikrullah akan mencakup makna mengajak ma'ruf dan mencegah mungkar. Shalat akan dapat menjauhkan pelakunya dari perbuatan yang fabsya' dan munkar (Fajar, 2015: 27). Perbuatan fabsya' merupakan perbuatan yang buruk, jelek, jorok, cabul, kikir, bakhil, dan kata-kata kotor, iyitu kata yang tidak dapat diterima oleh nalar akal sehat. Sebagian mufassir mengartikan kata fahsya' ini dengan "zina". (Munawir, 2000: 1113). Sedangkan kata "mungkar " sebagaimana dinyatakan oleh Abul Aliyah yang dikutip Fajar Kurnianto dinyatakan bahwa munkar adalah setiap amalan / tindakan yang dilarang oleh agama 
Islam, yang di dalamnya tercakup seluruh dosa dan kemaksiatan, di mana hal itu bersumber dari kemusyrikan. Pendapat lain menyatakan bahwa munkar merupakan kumpulan dari berbagai kejelekan. Dalam pandangan Syari'ah dan akal kejelekan adalah menyekutukan Allah yang disebut musyrik, menyembah berhala dan qath'u al-silah al-rrabmi (Fajar, 2015: 27) .

Pembiasaan sikap sosial yang biasa dilakukan di tiga SMK adalah jabat-tangan antara guru dan siswa, antar siswa dengan guru dan karyawan. Setiap pagi para guru menjemput siswa yang datang di dekat pintu gerbang sekolah. Bersalaman atau berjabat tangan juga merupakan kekhasan bagi orang yang memiliki kelembutan hati. Orang yang memiliki kelembutan hati biasanya selalu membiasakan diri untuk untuk mengajak bersalaman kepada siapa saja yang ditemuinya. Selain itu, dengan bersalaman juga akan memberikan dampak pada hal-hal yang positif lainnya, seperti menghindari percekcokan, permusuhan dan kedengkian. Hal ini sebagai mana hadis riwayat Imam Malaik di mana Rasulullah menyatakan: berjabat tanganlah, karena berjabat tangan akan menghilangkan kedengkian. Saling memberi hadiahlah, karena saling memberi hadiah itu akan menumbuhkan rasa saling cinta dan menghilangkan permusuhan." Bersalaman juga merupakan salah kekhasan orang yang berhati lembut. Orang yang memiliki berhati yang lembut, InsyaAllah akan selalu terbiasa bersalaman dengan siapapun yang dijumpainya. Kecuali itu, dengan bersalaman juga akan berdampak secara positif dalam hal menghilangkan permusuhan dan kedengkian hatii. Hal ini sebagai mana hadis riwayat Imam Malaik di mana Rasulullah menyatakan: berjabat tanganlah, karena berjabat tangan akan menghilangkan kedengkian. Hendaklah kalian saling memberi hadiahlah, karena hal itu akan menumbuhkan rasa saling cinta serta menghilangkan permusuhan." Hasil penelitian yang dimuat dalam journal of the Cognitive Neuroscience menyatakan bahwa interaksi antar manusia akan berjalan lebih lancar jika diawali dengan berjabat tangan (Setiawan, https://lifestyle.kompas.com, akses 3 Juli 2018). Berdasarkan teori ini, maka pembiasaan bersalaman atau berjabat tangan yang dilakukan di tiga SMK tersebut akan berdampak pada pengembangan karakter siswa. 


\section{Ekstra Kurikuler}

Ekstra Kurikuler merupakan bagian dari program sekolah yang harus dilaksanakan di SMK Diponegoro Kota Salatiga, SMK AlFalakh Kota Salatiga, SMK Muhammadiyah Kota Salatiga) Program Ekstra Kurikuler yang terdapat di ketiga SMK tersebut meliputi Pramuka, Paskibraka, seni rabbana, seni baca al-Qur'an dan kajian kitab kuning "Muraqil Ubudiyah" sehabis jamaah shalat Dhuhur. Semua kegiatan ekstra kurikuler tersebut ikut mendukung penguatan karakter siswa. Kegiatan kepramukaan dan Paskibraka akan menumbuhkan skill, kesetiakawanan, kedisiplinan dan kejujuran siswa yang kesemuanya itu merupakan indikator terbentuknya karakter siswa ( Surya Suwandito, Ngamilah, April 20, 2018).

Ki Hajar Dewantoro menganggap perlu adanya pendidikan kesenian untuk memperhalus kepribadian siswa yang sangat memungkinkan untuk dibentuk dan dikembangkan. Dalam proses pembelajaran seni, anak dilatihkan untuk mengaktifkan kerja otak kanan dan kiri secara seimbang. Pendidikan seni memberikan ruang kepada anak untuk belajar dengan cara yang menyenangkan (Wetie, 2012: 12 ).

Berdasarkan teori Ki Hadjar Dewantoro tersebut, maka seni Rebbana dan seni Baca al-Qur'an akan memberikan kontribusi terhadap pengembangan karakter Siswa pada kehalusan budi pekerti siswa di mana hal itu tampak pada interaksi antar sesama siswa.

\section{Keteladanan}

Keteladanan adalah hal-hal yang patut untuk diikuti, dituru dan dicontoh (Karnisa, 2006; 534 ). Secara umum, orang merasa lebih gampang menanggkap hal-hal yang nyata atau kongkrit ketimbang yang abstrak. Oleh karena itulah Pimpinan Sekolah mengambil keteladanan sebagai media pengembangan karakter peserta didiknya. Pimpinan Sekolah menekankan para guru dan karyawan agar dapat memberikan keteladanan bagi peserta didik. Keteladanan yang diprogramkan oleh Sekolah seperti adanya 
lingkungan Sekolah bebas asap rokok. Guru dan karyawan tidak diperbolehkan merokok di kawasan lingkungan sekolah. Guru dan karyawan diwajibkan mengikuti kerja bakti membersihkan di sekitar lingkungan sekolah, wajib mengikuti shalat jamaah shuhur dan shalat Dhuha yang telah diprogramkan oleh Sekolah. Semuanya itu adalah keteladanan yang diberikan oleh semua unsur sekolah mulai dari Kepala Sekolah sampai Karyawan kepada peserta didik dalam rangka pengembangan pendidikan karakter. Dengan keteladan tersebut siswa akan mudah untuk mengikuti kegiatan-kegiatan sekolah yang secara tidak langsung akan membentuk karakter mereka.

\section{Muatan Lokal}

Mulok atau Muatan lokal adalah kegiatan kurikuler yang bertujuan untuk meningkatkan dan mengembangkan kompetensi yang disinergikan dengan kekhasan dan keunggulan daerah, yang sekiranya materinya tersebut tidak dapat dimasukkan ke dalam mapel yang ada. Maka sebagai solusinya subtansi mata pelajaran muatan lokal ditentukan dan ditetapkan oleh sekolah, yang tidak terbatas pada mata pelajaran keterampilan saja (Mansur, 2011:30). Terdapat empat mata pelajaran di SMK Kota Salatiga yang masuk kategori muatan lokal. Empat mata pelajaran tersebut adalah Kitab Muraqil Ubudiyah serta ta'limu al-Muta'alim yang diajarkan di SMK al-Falakh, Aswaja yang diajarkan di SMK Diponegoro dan KeMuhammadiyahan yang diajarkan di SMK Muhammadiyah.

Kajian kitab kuning " Muraqil Ubudiyab " yang dilakukan sehabis shalat jamaah Dhuhur selama 30 menit di SMK al-Falakh dimaksudkan untuk membekali siswa dalam etika beribadah, baik ibadah yang bersifat mahdlah ataupun ibadah sosial. Karena kitab ini merupakan karya besar Imam Abu Hamid bin Muhammad alGhazali yang membahas tentang perpaduan ilmu Fiqih dan Ilmu Tashawwuf. Dengan demikian kajian ini sangat memberikan kotribusi terhadap pengembangan karakter siswa, karena materi yang termuat dalam kitab Muraqil Ubudiyah itu sendiri sarat dengan materi pendidikan karakter. 
Sedangkan kitab Ta'lim al-Muta'alim diajarkan untuk membekali siswa dalam etika mencari ilmu, berinteraksi dengan guru dan karyawan serta berinteraksi dengan sesama siswa. Ta lim al-muta allim merupakan kitab yang ditulis oleh Imam al-Zarnuji yang memuat tentang etika dan estetikan pembelajaran. Ta lim AlMuta allim merupakan panduan yang mampu memacu akhlak atau karakter peserta didik, mengingat kitab ini menjelaskan tentang akhlakul karimah. Istilah " pendidikan" dalam kitab Ta'lim AlMuta allim yang merupakan muatan lokal disebut at-ta'lim yang biasanya diterjemahkan dengan "pengajaran", (al-Zarmuji, 2006: VIII). Istilah pada saat ini yang popular adalah tarbiyah, karena menurut Athiyah Abrasyi Al-tarbiyah adalah term yang mencakup seluruh aktifitas pendidikan. Sebagaimana dikutip oleh Dr. Suwito, Menurut Hasan langgulung, - sebagai mana yang dikutip Suwitoyang dimaksud dengan pendidikan akhlak adalah suatu proses yang mempunyai tujuan untuk menciptakan pola-pola tingkah laku tertentu pada anak atau orang yang sedang di didik. Sedangkan akhlak, menurut pendekatan etimologi berasal dari kata Arab dalam bentuk jama' yang bentuk mufradnya "khuluqun" (خلق) yang menurut loghat diartikan tingkah laku, budi pekerti, perangai, atau tabiat. Kalimat tersebut mencakup aspek-aspek persesuaian dengan perkataan "khalkun" yang memiliki arti kejadian, dan erat hubungannya dengan kata "khaliq" yang memiliki arti "yang menciptakan".

Muatan lokal yang lain adalah Aswaja yang diajarkan di SMK Diponegoro. Aswaja dalam perspektif bahasa terdiri dari tiga kata, Ablu, Al-Sunnah, dan Al-Jama'ah. Kata Ablu berarti keluarga, komunitas, atau pengikut. Kata al-Sunnah memiliki arti " jalan atau karakter. Sedangkan kata al-Jamaah berarti perkumpulan. Sementara makna Sunnah secara terminologi memiliki pengertian segala sesuatu yang dilakukan oleh Nabi Muhammad SAW., baik berupa ucapan, tindakan, maupun sikap. Sedangkan al-Jamaah secara terminologi memiliki arti sesuatu yang telah menjadi kesepakatan para sahabat Nabi SAW. pada masa Khulafab AlRasyidin yaitu Abu Bakar ash-Shiddiq, Umar bin Khathab, Utsman bin Afan dan Ali bin Abi Thalib. Dengan demikian pengertian Ablusssunnah Wal Jamaah secara utuh sebuah komunitas dari orang-orang yang senantiasa menjadikan sunnah Nabi Muhammad SAW dan jalan para Sahabat Nabi sebagai pedoman dalam beragama, 
baik dalam berakidah, beribadah, maupun bermuamalah ( FKI LIM, 2010 : 2). Sedang kata Jama'ah mengandung beberapa pengertian, di antara kelompok intelektual dan ulama, golongan yang yang bergabung dalam suatu pemerintahan yang dipimpin oleh seorang amir; komunitas yang terdiri dari orang-orang yang berintegritas atau memiliki moral atau akhlak yang baik, keimanan dan ketaqwaan yang kuat; dan golongan mayoritas kaum muslimin (Arlana, 2000: 33). Dalam menjelaskan maksud ablussuna wal jamaah, dipakai lima istilah utama yang diambil dari Al Qur'an dan Hadits sebagai landasan dalam bermasyarakat yang disebut dengan konsep Mabadiu Khaira Ummat yakni sebuah gerakan untuk mengembangkan identitas dan karakteristik anggota Nahdlatul 'Ulama dengan pengaturan nilai-nilai mulia dari konsep keagamaan Nahdlatul 'Ulama. Lima istilah tersebut adalah tawaasuth (moderat), al-I'tidal (sederhana), al-Tasaamuh (toleransi), al-Tawaazun (berimbang), dan amar ma'ruf-nabi mungkar (menyuruh kebaikan dan mencegah kemunkaran).

Muatan lokal berikutnya adalah "Ke-Muhammadiyahan" yang diajarkan di SMK Muhammadiyah. Mata Pelajaran KeMuhammadiyahan sebenarnya mirip dengan mata pelajaran Pendidikan Agama Islam (PAI), hanya saja dikemas sesuai konsep dasar ideologi Muhammadiyah dalam bergama. Menuru Kunto Widjoja (1996: 46-47), bentuk keberagamaan dikategorisaikan sebagai bentuk keberagamaan simbolik dan keberagamaan substantif. Keberagamaan simbolik hanya menekankan simbolsimbol spiritualitas agama sebagai ciri budaya spiritual, sedangkan keberagamaan substantif ditunjukkan oleh pemikiran dan pemahaman agama yang syariatnya dilaksanakan secara konsekuen.

Dalam konteks keberagamaan Muhammadiyah, Munir Mulkhan menemukan empat tipologi keberagamaan Islam murni dalam masyarakat yang dikelompokkan kedalam bentuk keberagamaan al-Ikhlas, Kiai Dahlan, Marmud/Munas, dan Munu. Pertama, keberagamaan al-Ikhlas, yaitu: kelompok pengikut yang lebih skripturalis dan tekstual dalam memahami dan menerapkan ajaran Islam murni. Mereka mengecam keras praktik keagamaan yang tidak sama dengan mereka. Kedua, keberagamaan Kyai Dahlan, yaitu: kelompok pengikut yang secara konsisten berusaha 
menyesuaikan pengamalan Islam murni, tetapi bersikap inklusif dan toleran terhadap praktik TBC baik pengikut ataupun bukan, juga pemeluk agama lain. Ketiga, keberagamaan Munu, yaitu: kelompok mayoritas pengikut yang terus memelihara tradisi TBC dan lebih berorientasi "magis", termasuk melaksanakan berbagai upacara ritual yang sulit ditemukan dalam buku tarjih. Dan keempat, keberagamaan Munas/Marmud, yaitu: kelompok pengikut sinkretis yang paling terbuka dan pragmatis. Mereka suka berdoa, slametan dan tahlilan untuk tujuan magis; mereka kurang menaati aturan syariah dan sering terlibat upacara sinkretik, hingga tindakan sekuler (Munir Mulkhan; 2000 : 248-255).

Fakta dalam penelitian menunjukkan bahwa dalam pembelajaran agama melalui materi ke-Muhammadiyahan tidak cukup di dalam kelas, melainkan juga dilaksanakan di luar kelas dan di luar jam pelajaran, terutama pada tataran penkontekstualisasian terhadap materi ke-Muhammadiyahan. Sebagai contoh dalam kajian surat al-Ma'un yang menekankan aspek kepedulian sosial, pengaplikasiannya siswa langsung diajak ke berbagai Panti Asuhan dan Keluar untuk memberikan santunan pada orang-orang yang tidak mampu yang berada di Sekitar Sekolah dengan menyerahkan santunan yang diperoleh dari siswa itu sendiri.

\section{Pembudayaan Sekolah}

Budaya sekolah merupakan acuan warga sekolah yang berupa nilai-nilai yang diperoleh dari sekolah itu sendiri maupun lingkungan yang dipraktikkan dalam kehidupan sehari-hari sebagai ciri khas sekolah (Susilo, 2016; 567). Apabila budaya sekolah itu positif, ia akan mampu memberikan dorongan kepada segenap warga sekolah untuk saling bekerja sama, menumbuhkan partisipasi seluruh warga, mendorong munculnya ide-ide baru, serta memberikan kesempatan untuk berkreasi menuju pembaharuan di sekolah yang kesemuanya itu menuju pada pencapaian hasil terbaik. Budaya sekolah yang baik memiliki kemampuan untuk menciptakan iklim yang kondusif yang dapat memacu semua warga sekolah untuk belajar. Terciptanya suatu iklim bahwa belajar yang menyenangkan, merupakan suatu kebutuhan, bukan lagi keterpaksaan. Belajar yang muncul dari kesadaran diri 
sendiri, intrinsic motivation, bukan pakasaan dan tekanan dari luar, akan menumbuhkan suatu semangat di kalangan warga sekoalah. (AlArifin, 2012: https://ulilalbabjong: diakses 29 Juni 2018 ).

Hasil pengamatan penulis di lapangan menunjukkan adanya upaya pembudayaan hal-hal yang mengandung nilai-nilai positif bagi pembentukan karakter siswa. Hal-hal yang mengandung nilainilai positif tersebut seperti adanya budaya bebas asap rokok di lingkungan sekolah, perilaku 3 S (Salam, Senyum dan Sapa) di antara sesama warga sekolah, lingkungan bebas sampah, dan lingkungan bebas corat-coret. Hal-hal tersebut tertuang dalam bentuk tulisan yang indah yang terpampang di berbagai tempat di lingkungan sekolah.

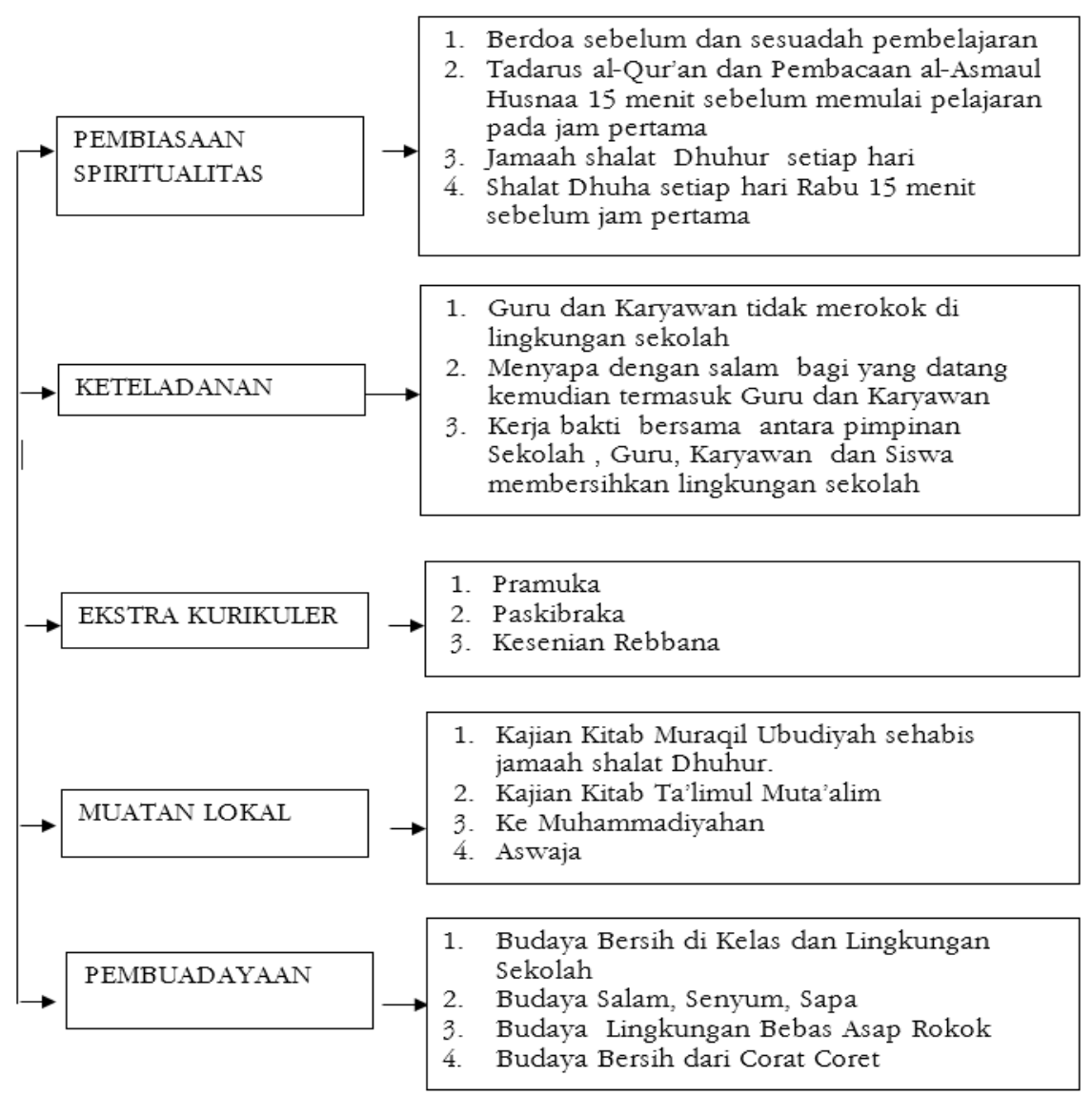

Diagram 2 : Model Pengembangan Pendidikan Karakter di Tiga SMK 


\section{Pelaksanaan Pengembangan Pendidikan Karakter}

Syukur (2015: 467-490) dalam penelitiannya menegaskan bahwa dalam pelaksanaan program diperlukan keterlibatan semua komponen organisasi (Syukur, Komponen dimaksud adalah unsur pimpinan sekolah, guru, karyawan dan siswa. Di tiga SMK AlFalakh, Diponegoro dan SMK Muhammadiyah dalam upaya pengembangan pendidikan karakter dimulai dari penyusunan Visi dan Misi Sekolah sebagaimana hal ini sudah dijelaskan di muka. Proses penyusunan Visi dan Misi tersebut pihak sekolah melibatkan berbagai komponen. Kegiatan penyusunan Visi dan Misi dimulai dari penyiapan konsep oleh Kepala Sekolah yang kemudian dibahas dalam suatu forum yang di dalamnya hadir unsur pimpinan sekolah, guru, karyawan, perwakilan siswa, perwakilan wali murid dan stakeholder. Dalam pembahasan tersebut muncul berbagai masukan untuk penyempurnaan Visi dan Misi Sekolah. Setelah mendapatkan masukan-masukan yang cukup maka Kepala Sekolah mengesahkan. Tahap berikutnya adalah sosialisasi ke berbagai komponen sekolah yang meliputi dewan guru, karyawan, yayasan dan seluruh siswa dalam bentuk lisan maupun tulis.

Demikian juga dalam penyusunan program penguatan pendidikan karakter yang berangkat dari Visi dan Misi tersebut. Hanya saja penyusunan konsep dilakukan oleh Wakil Kepala Sekolah bidang kesiswaan dengan berkoordinasi dengan Wakil Kepala Sekolah bidang Kurikulum dan Pengajaran. Kemudian konsep tersebut dimatangkan di forum rapat dewan guru dan karyawan beserta pihak yayasan. Setelah mendapatkan masukan dan kesepakatan dari dewan guru dan yayasan maka Kepala Sekolah mengesahkannya (Siswanto dan Ngamilah, April 25, 2018). Dalam upaya penguatan pendidikan karakter, ketiga sekolah menerapkan model yang hampir sama yaitu Pembiasaan Spiritual, Muatan Lokal, Ekstra Kurikuler, Keteladanan dan Pembudayaan Sekolah sebagaimana sudah dibahas di muka.

Dari uraian rancangan program pengembangan pendidikan karakter tersebut penulis tuangkan dalam diagram sebagai berikut: 


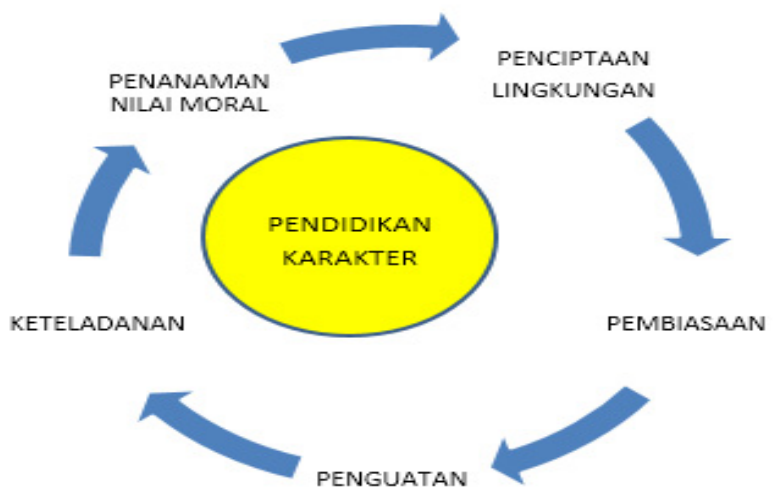

Dalam pelaksanaan program tersebut, Wakil Kepala Sekolah bidang Kesiswaan sebagai leading sector, melibatkan berbagai unsur sekolah mulai dari Kepala Sekolah, Dewan Guru, Karyawan, dan Jam'iyah sesuai dengan kompetensi masing-masing. Keterlibatan Kepala Sekolah dalam bentuk pemberian kebijakan terhadap program-program yang mendorong tumbuh dan berkembangnya karakter siswa, disamping memberikan keteladanan secara kongkrit kepada seluruh warga sekolah. Guru memiliki keterlibatan secara langsung dalam pelaksanaan program-program pengembangan karakter tersebut di bawah koordinasi Wakil Kepala Sekolah Bidang Kesiswaan dan Wakil Kepala Sekolah bidang Kurikulum dan Pengajaran. Karena dewan gurulah yang bertanggung jawab secara langsung akan pengembangan karakter siswa. Pengembangan karakter di ketiga sekolah tersebut, di samping melalui pelaksanaan program-program tersebut, juga dilaksanakan secara integrasi dalam semua mata pelajaran. Dengan demikian semua guru terlibat secara langsung dalam pengembangan karakter siswa. Pengadministrasian mulai dari pengkonsepan Visi dan Misi Sekolah, Program pengembangan karakter ditangani oleh staf dan karyawan sekolah di bawah koordinasi Kepala Bagian Tata Usaha Sekolah. Sementara keterlibatan Yayasan dan Jam'iyah adalah memberikan dorongan baik secara moril maupun materiil terhadap terlaksananya program-program pengembangan karakter tersebut, serta pemantauan perilaku siswa ketika di rumah dan di luar rumah dan sekolah. Karena Jam'iyah memiliki tugas yang 
sangat stategis, yaitu memberikan keteladanan dan pemantauan kepada anaknya masing-masing, maka pihak sekolah tidak lepas membekali para orang tua siswa melaui Jam'iyah tentang programprogram pengembangan karakter yang dilakukan di Sekolah. Hal ini dimaksudkan untuk mengsinergikan antara apa yang dilakukan oleh sekolah dengan apa yang harus dilakukan oleh para orang tua siswa.

Dari uraian pelaksanaan program pengembangan karakter siswa di ketiga sekolah tersebut penulis tuangkan dalam diagram sebagai berikut ;

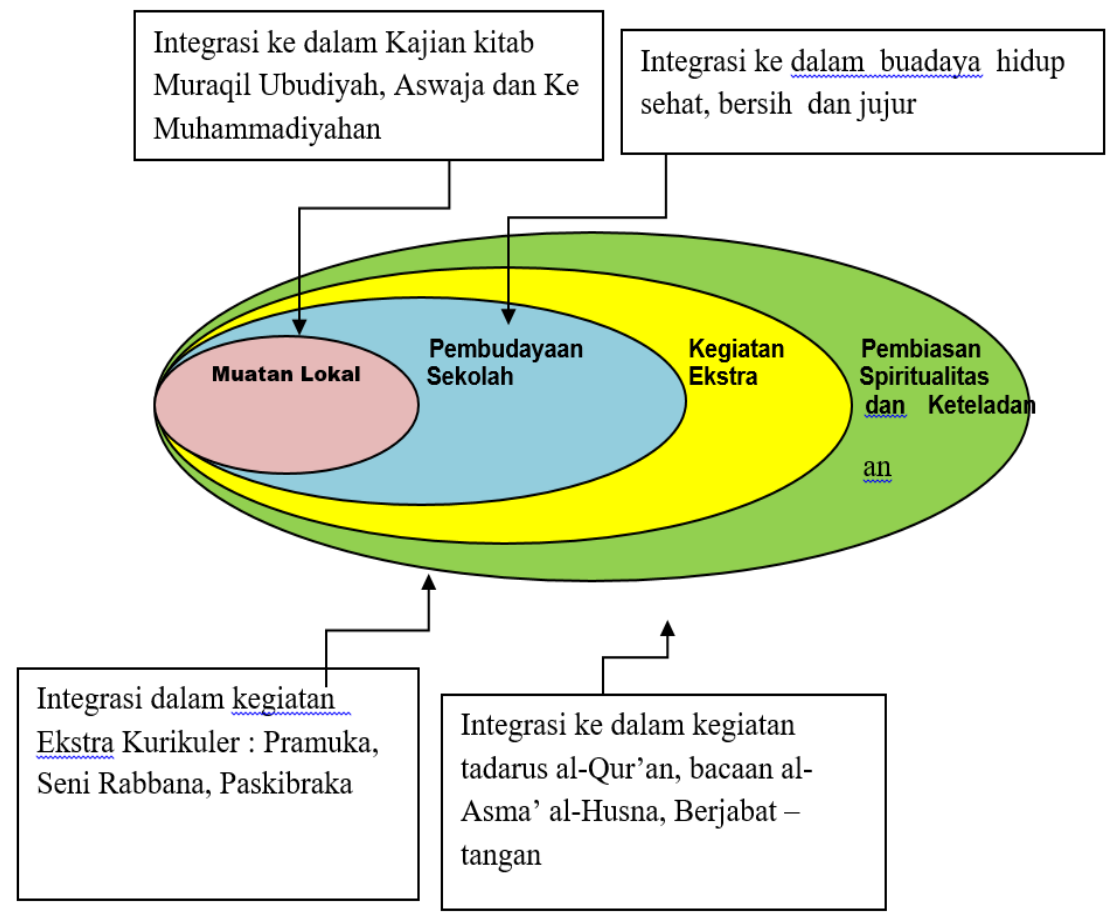

Sumber : Data terolah

\section{Efektifitas Pengembangan Pendidikan Karakter di Tiga Sekolah}

Untuk memberikan gambaran sejauh mana efektifitas pengembangan karakter di tiga sekolah, penulis akan menguraikan data data tentang situasi dan kondisi siswa, baik yang penulis 
peroleh melalui pengamatan, wawancara maupun dokumendokumen yang penulis dapatkan. Berdasarkan pengamatan penulis di lapangan, siswa di ketiga sekolah berperilaku yang sangat positif dan menunjukkan bahwa siswa memiliki karakter yang baik. Saling tegur-sapa, senyum dan salam di antara para siswa penulis temui di ketiga sekolah ini.

Wakil Kepala Sekolah bagian Kesiswaan SMK Al-Falakh menuturkan bahwa dengan adanya muatan lokal yang berupa kajian kitab " Muraqil Ubudiyab" yang sarat dengan nilai-nilai akhlak, demikian juga dengan kegiatan-kegiatan ekstra kurikuler sangat efektif untuk pembentukan karakter siswa. Hal itu dapat dilihat terwujudnya perilaku siswa yang toleran, saling tolong-menolong, jujur, dapat mengendalikan diri dan bertanggung jawab. Komunikasi antara siswa dan guru maupun antar siswa sehari hari di luar proses pembelajaran sering menggunakan bahasa jawa yang halus di mana hal ini menunjukkan adab kesopanan yang tinggi. Hal yang sama juga dituturkan oleh Wakil Kepala Sekolah bagian Kesiswaan SMK Diponegoro dan SMK Muhammadiyah. Wakil Kepala Sekolah Muhammadiyah menuturkan bahwa perilaku kejujuran siwa juga tercermin pada perilaku siswa ketika melaksanakan praktik di bengkel. Peralatan bengkel tidak pernah ada yang hilang. Para Siswa dengan kesadaran mereka sendiri selalu mencatat barangbarang yang ada di bengkel sebelum mereka praktik dan sebelum mereka meninggalkan bengkel tempat praktik, mereka selalu mengecek peralatan sesuai yang ada dalam catatan mereka sebelum praktik. Demikian juga setiap ada barang milik siswa atau guru yang tertinggal di kelas atau di tempat lain yang masih dilingkungan Sekolah selalu barang tersebut dapat ditemukan kembali. Siswa di ketiga Sekolah tidak pernah terlibat tawuran dan aksi corat-coret baju ketika pengumuman lulusan Ujian Nasional. Sesuai harapan Standar Kelulusan pada Kurikulum 2013 yaitu terpenuhinya sikap spiritual, sikap sosial disamping pengetahuan dan keterampilan. Siswa selalu melaksanakan tugas-tugas yang diberikan oleh guru, baik pekerjaan rumah (PR) maupun tugas tugas lain. Efektifitas model pengembangan karakter juga tercermin dengan diraihnya berbagai prestasi baik di bidang mapel, olah raga, kesenian dan keagamaan (Siswanto dan Ngamilah, Mei 27, 2018 ). 
Namun demikian, sekolah tidak menutup mata, masih adanya sebagian kecil siswa yang bermasalah di sekolah seperti pulang sebelum waktunya (bolos), terlambat tiba di rumah ketika pulang sekolah. Namun hal itu presentasenya sangat kecil. Biasanya siswa yang bermasalah seperti itu dilakukan oleh siswa pindahan yang memang sudah bermasalah di sekolah sebelumnya, dan juga disebabkan siswa tersebut berasal dari keluarga yang brokenhome yang banyak dipengaruhi oleh tingkat pendidikan orang tua. Kondisi yang demikian menjadi kendala tersendiri bagi Sekolah dalam pengembangan karakter siswa (Siswanto dan Ngamilah, Mei 27, 2018). Dalam menghadapi siswa yang seperti ini, biasanya sekolah mengadakan penanganan secara khusus, pendekatan persuasif dan homevisit.

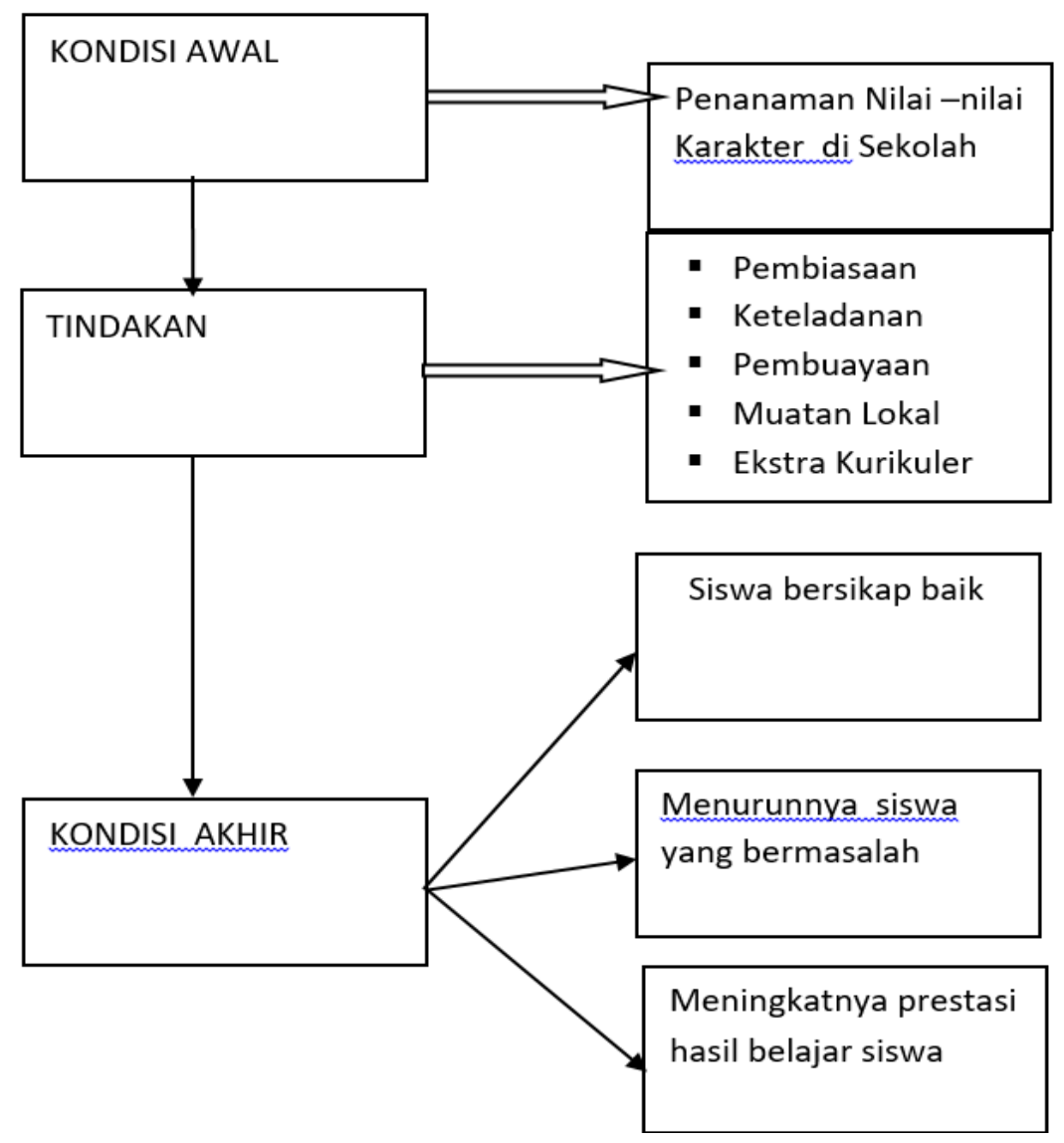

Sumber : Data terolah 


\section{Kesimpulan}

Penelitian pengembangan pendidikan karakter di tiga SMK Kota Salatiga yaitu SMK Al-Falakh, SMK Diponegoro dan SMK Muhammadiyah, memberikan gambaran, bahwa ketiga Sekolah Menengah Kejuruan tersebut telah melaksanakan pengembangan pendidikan karakter dengan model yang hampir sama, yaitu dengan pembiasaan, keteladanan, pembudayaan sekolah, muatan lokal dan ekstra kurikuler. Akan tetapi berbeda dalam muatan materinya, terutama materi pelajaran muatan lokal. Di SMK Al-Falakh muatan lokal berupa kajian kitab kuning dengan fokus kitab Muraqil Ubudiyah, sementara di SMK Diponegoro dan SMK Muhammadiyah masing-masing dengan materi Ke-NU an dan Ke-Muhammadiyahan. Namun ketiga materi tersebut memiliki karakter yang sama yaitu muatan religius. Perbedaan lainnya ada pada penekanan pembiasaan menjadi ciri SMK Al-Falakh dan SMK Diponegoro bersifat spiritualitas, sedangkan pada SMK Muhammadiyah penekanan pada amaliah kongkrit.

Dalam pelaksanaan program pengembangan karakter, ketiga SMK melibatkan semua unsur sekolah yang terdiri dari pimpinan sekolah, guru, karyawan, siswa, yayasan dan orang tua siswa yang terwadahi dalam organisasi "Jam'iyyah.

Efektifitas model pengembangan pendidikan karakter di tiga SMK Kota Salatiga yang berada di bawah naungan Yayasan Islam dapat dilihat pada perilaku siswa dalam kesehariannya yang senantiasa mengedepankan persahabatan, kejujuran, kedamaian, sportifitas dan kedisiplinan. 


\section{Daftar Pustaka}

An Nahlawi, Abdurrahman, 1996, Pendidikan Islam di Rumah, Sekolah, dan Masyarakat, Jakarta: Gema Insani Press.

Marini, Marita: Character Building Throuch Teaching Learning Process: Lesson In Indonesia,

A.Koesoema, .Doni, 2007, Pendidikan Karakter: Strategi Mendidik Anak di Zaman Global, Jakarta : Grasindo.

Depdiknas RI., 2014, Pengembangan Karakter Sekolah. Jakarta: Depdiknas RI..

https://lifestyle.kompas.com/read/2015/05/06/100000520/Fakta. Berjabat.Tangan.yang.Baiknya.Anda.Ketahui.

Kurnianto, Fajar, 2015, Menyelami Bacaan Shalat, Jakarta : Gramedia.

Kemendiknas, 2011, Undang-undang Sistem Pendidikan Nasional, Jakarta: Sinar Grafika, Cet. IV.

Kaimudin, Implementasi Pendidikan Karakter dalam Kurikulum 2013, dalam file://C:/Users/FUAH2/AppData/Local/Temp/7895-1-PB.pdf

Mufid, Muhammad, 2013, Strategi Pembentukan Karakter Religius Siswa Di Ma'bad Al -Qalam MAN 3 Malang, Malang, Universitas Islam Negeri Maulana Malik Ibrahim,.

Ngamilah, 2017, Kebijakan Pemenerintah di Pendidikan Akblak, Yogyakarta: Kurnia Kalam Semesta.

Ratnaning Eka Astuti, : 2013,, Pembentukan Karakter Siswa Berbasis Agama (Studi Kasus Di MAN Kediri II Kota Kediri), Malang, Universitas Islam Negeri Maulana Malik Ibrahim.

Rusuli, Izzatur, 2014, Refleksi Teori Belajar Behavioristik dalam Perspektif Islam, Jurnal Pencerahan, Vol. 8 Nomor 1, 2014.

Syukur, Fatah, 2015, Model Menejemen Madrasah Aliyah Efektif, Jurnal Inferensi V 9 No 2

Suhail, Ahmad Kusyairi, 2014, "Rahasia Kecerdasan melalui AlQur'an”, Ummi Vol. XXVI, No. 6. 
Susilo, Muhammad Joko, 2016, Strategi Menciptakan Budaya Sekolah Yang Kondusif Melalui Paradigma Sekolah-Sekolah Unggulah Muhammadiyah: Prosiding Syabium, Jogyakarta, UAD

Lickona, Thomas, 1991, Educating for Character: How Our School Can Teach Respect and Responsibility. New York, Toronto, London, Sydney, Aucland: Bantam books..

Undang-undang Republik Indonesia Nomor 20 tahun 2003 tentang Sistem Pendidikan Nasional (Sisdiknas) Bab II pasal 3

Zuchdi,, Darmiyati, 2008, Humanisasi Pendidikan: Menemukan Kembali Pendidikan yang Manusiawi. Jakarta: PT. Bumi Aksara. 